\title{
PROFESSOR LUIS DE CASTRO IN THE CHAIR OF MEDICAL HISTORY, UNIVERSIDAD DE VALLADOLID, SPAIN
}

To the Chairs of Medical History in the Universities of Madrid, Salamanca and Valencia must now be added that of the School of Medicine, University of Valladolid, to which the Dean and Faculty unanimously elected Dr. Luis de Castro García (born 1912), himself a graduate of that university. Dr. Castro, who is also Ph.D.Litt., had been Assistant Professor in Medical History from 1959 and in recent years was in charge of the Department, giving a full programme of lectures and presiding over the compulsory examinations that are becoming a regular feature in medical training throughout Europe.

Professor Castro, who also trained in Germany and Italy, is a qualified sculptor and is well known for his book, Un médico en el museo (1954)-in which he analysed from the medical standpoint the rich collection of sculptures in the Valladolid Museum - as well as for many papers on medical aspects of art. In his Department Professor Castro has built up a great collection of over 14,000 photographic reproductions and slides dealing with this special field.

\section{PROFESSOR ADALBERTO PAZZINI HONOURED BY THE UNIVERSITY OF ATHENS}

Professor Adalberto Pazzini, the Director of the Institute of the History of Medicine at the University of Rome, has been appointed doctor honoris causa by the Faculty of Medicine and Surgery of the University of Athens, in recognition of his contributions to scholarship in the History of Medicine.

\section{PROFESSOR ERNST W. STIEB APPOINTED HISTORIAN OF PHARMACY AT THE UNIVERSITY OF TORONTO}

To give academic leadership to developing the history of pharmacy as a special field in Canada, the University of Toronto has invited Professor Ernst W. Stieb of the University of Wisconsin to accept a full professorship in the subject. The move puts pharmacy in the forefront of a broader programme in the history of the sciences now unfolding at the University of Toronto, where a historian of biology and a historian of physical science also will take up appointments this year.

Dr. Stieb earned a Doctor of Philosophy degree in the history of pharmacy at the University of Wisconsin (1959), working with Professor Glenn A. Sonnedecker; and meanwhile, he has been seasoned as a professional historian of pharmacy through service on the faculty of the University of Wisconsin and (since 1957) as Secretary of the American Institute of the History of Pharmacy. Dr. Stieb will continue his association with the Institute as a contributing editor of Pharmacy in History. This year he received the Edward Kremers Award for distinguished historical writing about pharmacy, recognizing especially his book, Drug Adulteration: Detection and Control in Nineteenth-Century Britain (Madison, 1966). Dr. Stieb has published various historical papers, and is currently completing a booklet on the history of the American College of Apothecaries. 